\title{
Low-Density Lipoprotein Receptor-Related Protein 6
}

National Cancer Institute

\section{Source}

National Cancer Institute. Low-Density Lipoprotein Receptor-Related Protein 6. NCI

Thesaurus. Code 195415.

Low-density lipoprotein receptor-related protein 6 (1613 aa, $180 \mathrm{kDa}$ ) is encoded by the human LRP6 gene. This protein plays a role in the modulation of cell communication. 